\title{
EDUCAÇÃO E LEGISLAÇÃO: UM VIÉS HISTÓRICO-DOCUMENTAL PARA O SURGIMENTO DO LIVRO DIDÁTICO E SUA INCIDÊNCIA NA MEDIAÇÃO DO ENSINO E DA APRENDIZAGEM ENTRE PROFESSOR E ALUNO
}

\begin{abstract}
EDUCATION AND LEGISLATION: A HISTORIC-DOCUMENTAL PERSPECTIVE TO THE EMERGENCE OF THE TEACHING BOOK AND ITS INCIDENCE INTO THE TEACHING AND LEARNING MEDIATION BETWEEN TEACHER AND STUDENT
\end{abstract}

Humberto Pires Junior | Lattes | betoo.pires@gmail.com Universidade Federal de Santa Catarina

Resumo: Dada a situação da educação no Brasil atualmente, este artigo tem como premissa uma abordagem da legislação - Constituição Federal e Lei de Diretrizes e Bases da Educação Nacional, vigentes e revogadas -, em um percurso histórico-documental desde as circunstâncias introdutórias do surgimento da educação análogas ao trabalho e às necessidades de comunicação também inerentes ao trabalho como fator fundante do homem para sua existência e subsistência até os momentos atuais. Esse artigo tem como objetivo identificar a forma como a legislação regimenta a escola, sob a perspectiva da incidência do livro didático em sala de aula e discussões a respeito da finalidade desse material, com amparo em leituras a respeito da natureza da educação, da legislação e da realidade social que concerne à escola enquanto instituição.

Palavras-chave: Educação. Legislação. Livro didático.

Abstract: This article follows a historical-documental perspective of the beginning of the education process that attend the labor as well as the communication needs at work as part of human existence and subsistence up to now. Thus, it focuses on the Brazilian laws, such as the Federal Constitution and Lei de Diretrizes e Bases da Educação (LDB) that are still working or not on the current educational situation in Brazil. This article aims to identify how the legislation influences the school about the teaching book use in class and the discussion regarding its use based on readings about education, legislation and social reality relate to school as an institution.

Keywords: Education. Legislation. Teaching book. 


\section{Considerações iniciais}

Levando em consideração as perspectivas de surgimento da comunicação e da educação, oriundas do trabalho e da interação, enquanto elemento fundante do homem para sua subsistência, existência e formação, é necessário discutir sobre as convenções posteriormente estabelecidas, como as leis que regimentam a vida em sociedade, bem como sobre o que se estabelece como direito - o que direciona a uma outra reflexão sobre a realidade. Para, então, situar os direitos comuns à sociedade principalmente no que diz respeito à educação e sua condição de existência atrelada a uma análise social atual que perpassa a história política e jurídica do país e dos anseios por uma educação pautada na promoção do homem na sociedade.

\section{A natureza da educação}

É importante refletir sobre a natureza da educação na sociedade quando se pensa que é o homem quem produz sua própria existência e que é o homem, diferentemente dos animais, que necessita transformar a natureza, adaptando-a a si e não o contrário. Essa adaptação da natureza ocorre por meio do trabalho, atividade humana cujo caráter é produtivo. De acordo com Demerval Saviani (2013, p.12), é possível compreender que "a educação é um fenômeno próprio dos seres humanos", porque "ela é, ao mesmo tempo uma exigência do e para o processo de trabalho, bem como ela é, ela própria, um processo de trabalho". Ou seja, a educação é produto do trabalho, bem como é constituinte do trabalho.

Esse processo de apropriação do homem ao conhecimento por meio da atividade humana difere da forma como acontece com os animais, de forma hereditária para a evolução, como sugere Leontiev:

A diferença fundamental entre os processos de adaptação em sentido próprio e os de apropriação reside no fato do processo de adaptação biológica transformar as propriedades e faculdades específicas do organismo bem como o seu comportamento de espécie. O processo de assimilação ou de apropriação é diferente: o seu resultado é a reprodução pelo indivíduo, das aptidões e funções humanas, historicamente formadas. Pode-se dizer que, é o processo pelo qual o homem atinge no seu desenvolvimento o que é atingido, no animal, pela hereditariedade, isto é, a encarnação nas propriedades do indivíduo das aquisições do desenvolvimento da espécie. (LEONTIEV, 1959, p. 180-181).

É a partir do entendimento da evolução por meio do trabalho exercido pelo homem na modificação da natureza, tanto para sua subsistência quanto para a sua formação, 
que se vê constituída a adaptação individual ao meio natural, processo de apropriação ausente no animal. Ou seja, é a partir do materialismo histórico. Sendo assim, completa Saviani, que "a razão pela qual o que define a essência da realidade humana é o trabalho, pois é através dele que o homem age sobre a natureza, ajustando às suas necessidades" (2013 [1980], p. 80-81) porque é trabalhando que o homem constrói o mundo histórico, o mundo da cultura e o mundo humano, e é por meio desse processo que a educação tem origem.

Pode-se entender que o trabalho, para a garantia de subsistência material (produção de bens materiais), pode ser denominado como "trabalho material". Já, quando se trata se produção do saber (como representação mental de objetivos reais como etapa que antecede a ação), o trabalho pode ser denominado como "não material”. Assim como também afirma Leontiev:

a transformação [...] manifesta-se como um processo de encarnação, de objetificação nos produtos da atividade dos homens, das suas forças e faculdades intelectuais e a história da cultura material e intelectual da humanidade manifesta-se como um processo, que exprime sob uma forma exterior e objetiva, as aquisições do desenvolvimento das aptidões do gênero humano. (LEONTIEV, 1959, p. 176-177).

A educação emerge do trabalho, pela ação do homem sobre a natureza, tanto para agir quanto para existir. Viver toma projeção de formação do homem, a consequência disso é a educação.

O surgimento da escola, partindo dessa natureza, no Brasil, acontece quando o meio de produção fundamental para a existência humana passa a assumir forma privada. Com as apropriações de terra, surge a classe de proprietários de terra e, por consequência disso, surge uma classe ociosa, uma classe que não precisa trabalhar (já que os proprietários de terra tinham sua subsistência garantida pelo trabalho de outros, seja pelo regime antigo ou escravista, seja pelo modo de produção medieval ou feudal).

[...] a escola aparecia como uma modalidade de educação complementar e secundária. Isto porque a modalidade principal de educação continuava sendo o trabalho, uma vez que a grande massa, a maioria, não se educava através da escola, mas através da vida, ou seja, do processo de trabalho. Era trabalhando a terra, garantindo a sua sobrevivência e a dos seus senhores que eles se educavam. Eles aprendiam a cultivar a terra cultivando a terra. E esse trabalho fundava determinadas relações entre os homens através das quais eles construíam a cultura e, assim, instruíam-se e formavam-se como homens. A maioria, portanto, educava-se pelo trabalho; só uma 
minoria tinha acesso à forma escolar de educação. (SAVIANI, 2013 [1980], p. 81-82).

É possível associar a origem da educação, de certa forma, à origem da linguagem como meio de interação. Podemos começar a compreender o que é lingua(gem) a partir da primeira tendência do pensamento filosófico linguístico ocidental, discutida por Volochínov (1928 [2013]) e considerada como base da linguagem. Para o autor, a lingua(gem) não pode ser entendida como sistema, mas como um acontecimento social, uma vez que ela nasce da necessidade de comunicação humana.

Para pensar a lingua(gem) é preciso, também, pensar a interação social, ampla e individualmente, na qual o sujeito deve estar incluso, uma vez que a enunciação é resultado de uma interação - a palavra dirige-se a um interlocutor. É preciso que se pense o sujeito e a lingua(gem) integrados na unicidade da situação social imediata, que produz conhecimento historicamente.

Em suma, Volochínov (2017 [1929], p. 224) defende a tese de que "a língua como um sistema estável de formas normativas idênticas é somente uma abstração científica”, que tinha por objetivo conceber um objeto de estudo estável e imutável, que não corresponde à realidade social da lingua(gem). "A língua é um processo ininterrupto de formação, realizado por meio da interação sociodiscursiva dos falantes" (VOLOCHÍNOV, 2017 [1929], p. 224), ou seja, a língua está sempre em construção, é heterogênea, social e ideológica. "As leis da formação da língua não são de modo algum individuais e psicológicas, tampouco podem ser isoladas da atividade dos indivíduos falantes" (VOLOCHÍNOV, 2017 [1929], p. 224), isso significa que as leis da formação da língua são sociológicas, pois a língua apenas se concretiza em enunciados presentes no meio social. Volochínov ainda ressalta que

[...] a criação da língua não coincide com a criação artística ou qualquer outra criação especificamente ideológica. No entanto, ao mesmo tempo, a criação linguística não pode ser compreendida sem considerar os sentidos e os valores ideológicos que a constituem. (VOLOCHÍNOV, 2017 [1929], p. 224-225).

Segundo o autor, a formação da língua ocorreu como uma necessidade livre e voluntária de interação. Por fim o autor afirma que "a estrutura do enunciado é uma estrutura puramente social” (VOLOCHÍNOV, 2017 [1929], p. 225), isso significa que o enunciado existe entre os falantes, que estão sempre compreendendo e respondendo a 
enunciados outros, e que a estrutura do enunciado é determinada, então, pela situação social mais próxima e pelo meio social mais amplo.

A efetiva realidade da linguagem não pode ser entendida como um sistema abstrato de formas linguísticas ou enunciação individual, expressão dos gostos, desejos, intenções e impulsos, deve ser compreendida como fenômeno social da interação verbal.

Volochínov (2013 [1930], p. 148) ressalta que “assim, nossa expressão mínima de uma necessidade biológica, natural, recebe inevitavelmente uma coloração sociológica e histórica: da época, do ambiente social, da classe social do falante e da situação real e concreta em que a enunciação ocorreu”, portanto a realidade linguística deve ser compreendida como um acontecimento social, tendo em vista que a enunciação é produto da interação verbal entre os interlocutores, determinada pela situação imediata ou contexto mais amplo que constitui o conjunto das condições de vida de dada comunidade linguística. Assim, como consequência, é possível compreender o surgimento da educação, pelo trabalho e pela necessidade de comunicação, produtos da atividade humana.

\section{O surgimento/desenvolvimento da escola no Brasil: uma leitura social}

A origem da escola, no Brasil, se deu, inicialmente, por influência da pedagogia católica cujo monopólio jesuíta da educação ocorreu praticamente até 1759 até a insurgência da pedagogia leiga inspirada no neoliberalismo clássico, o que não excluiu a influência católica na educação. No início do século XX, aparece a Nova Escola com uma "concepção moderna de filosofia da educação, das décadas de 1920 a 1950 houve a polarização entre os escolanovistas (preponderante até a década de 1960) e os católicos, "educação pública $x$ educação confessional". Com a crise da Escola Nova, adotou-se uma pedagogia tecnicista e junto à Lei n. 5692/71 com a tentativa de profissionalização universal do ensino de $2^{\circ}$ grau. Até que, na década de 1970, já durante o regime militar (influenciado pelo imperialismo estadunidense), tenta-se implantá-la, por meio de convênios entre Ministério da Educação e United States Agency for Internacional Development, de acordo com Saviani (2013 [1980], p. 77), "centrada nas ideias de racionalidade, eficiência e produtividade, que são características básicas da chamada pedagogia tecnicista”.

Desencadeado, então, um processo de crítica, ao regime militar, autoritário e tecnocrático, por conta da aversão de educadores à pedagogia tecnicista, amparado pela concepção crítico-reprodutivista de educação (como forma de reprodução das relações sociais de produção, mas crítica porque leva em conta determinantes sociais da educação - ou seja, educação com poder de determinar as relações sociais, independente da 
estrutura social). Ainda assim, sendo reprodutivista, a educação se dá em uma sociedade capitalista cuja reprodução é de interesse do capital. De acordo com Saviani, a concepção crítico-reprodutivista apenas

considerava a sociedade capitalista, de classes, como algo não suscetível a transformações, um fenômeno que se justifica em si mesmo; uma estrutura que se impõe compactadamente, portanto, de forma não contraditória. Em outros termos, não considerava esta sociedade contraditória, dinâmica e, portanto, em transformação. (SAVIANI, 2013 [1980], p. 79).

Em uma tentativa de evitar a perpetuação da situação vigente à época, professores acreditavam - e ainda acreditam - que a educação não necessitava ser reprodutora da situação de classe explorada - maioria - pela classe dominante - minoria -, quando se passa a pensar na educação por meio da situação e da condição social como transformadora da realidade em que se vive. Sendo assim, com a situação em que se encontra a sociedade, ainda hoje, entende a pedagogia histórico-crítica que "a tendência a secundarizar a escola traduz o caráter contraditório que atravessa a educação, a partir da contradição da própria sociedade" (SAVIANI, 2013 [1980], p. 84). Na medida em que estamos ainda numa sociedade de classes com interesses opostos e que a instrução generalizada da população contraria os interesses de estratificação de classes, ocorre essa tentativa de desvalorização da escola, cujo objetivo é reduzir o seu impacto em relação às exigências de transformação da própria sociedade.

\section{Educação, Constituição e LDB}

O Brasil tem sua Constituição de 1988 como a sétima ao longo de sua história. Perpassando pelo período imperial, primeira Constituição de 1824, pelo Brasil República, 1891, pela Era Vargas, 1934, pelo Estado Novo, 1937, Era Pós-Vargas, 1946, pelo regime militar, 1967, e a atual Constituição Cidadã de 1988.

É possível observar que, por comparação, a quantidade de vezes em que a palavra “educação" aparece na Constituição brasileira atual é superior às outras, sempre atribuindo ao Estado a garantia de educação à população.

A Constituição de 1988 apresenta a educação como direito do cidadão, uma vez que afirma no artigo 60 "São direitos sociais a educação, a saúde, a alimentação, o trabalho, a moradia, o transporte, o lazer, a segurança, a previdência social, a proteção à maternidade e à infância, a assistência aos desamparados, na forma desta Constituição", sendo de competência da União legislar, conforme o artigo 22을 redação de 2015, sobre "XXIV - di- 
retrizes e bases da educação nacional” e sendo comum à União, dos Estados, do Distrito Federal e dos Municípios, conforme artigo 23으, redação de 2015, "V - proporcionar os meios de acesso à cultura, à educação, à ciência, à tecnologia, à pesquisa e à inovação". Sendo assim, atribui responsabilidade ao Estado, como também às esferas municipal e estadual. Cabe mencionar que a educação tem como princípio, sendo dever do Estado e da família, de acordo com o artigo 205, "o pleno desenvolvimento da pessoa, seu preparo para o exercício da cidadania e sua qualificação para o trabalho”. Nesse contexto, Demerval Saviani posiciona-se com relação à função da educação, que

[...] destina-se à promoção do homem, caracterizando-se como uma comunicação entre pessoas livres em graus diferentes de maturação humana, numa situação histórica determinada. Dentro desse contexto, o processo ensino-aprendizagem é organizado intencionalmente de modo que se atinja adequada, eficaz e eficientemente o objetivo fundamental da educação: a promoção do homem. (SAVIANI, 2013 [1980], p. 129).

A Lei de Diretrizes e Bases da Educação Nacional (LDB) surge enquanto encaminhamento constitucional ainda na Constituição da República dos Estados Unidos do Brasil, resultado de uma Assembleia Nacional Constituinte, de 1934, pelo artigo 5º, com o intuito de "XIV - traçar as diretrizes da educação nacional”, como disposição preliminar de competência da União - ainda que esta fomentasse o "estímulo à educação eugênica", constatação da influência católica na educação, ou ainda "socorrer as famílias de prole numerosa”, característica assistencialista. A LDB surge efetivamente com o decreto da Lei n. 4.024 de 20 de dezembro de 1961 - 13 anos depois da apresentação do primeiro projeto de lei educacional.

De acordo com Rubem Barros (2016), a história dessa longa tramitação é reflexo das tensões que permeavam a educação e o Brasil. Pós-Segunda Guerra Mundial, em 1946, com a queda de Getúlio Vargas e a elaboração de uma nova Constituição Federal, que já previa lei que regesse a educação no Brasil. A comissão convocada por Clemente Mariani para elaboração de um anteprojeto era composta em sua maioria, segundo Demerval Saviani (2007), por membros que inclinavam para os escolanovistas. Além de ser um momento de oposição entre escola pública (defendida pelos escolanovistas) e privada (religiosa).

A primeira LDB de 1961, Lei n. 4.024/1961, trata da educação como direito de todos e assegurado "II - pela obrigação do Estado de fornecer recursos indispensáveis para que a família e, na falta desta, os demais membros da sociedade se desobriguem 
dos encargos da educação, quando provada a insuficiência de meios, de modo que sejam asseguradas iguais oportunidades a todos.” (Artigo 3oㅡ. À época, uma vitória para os que seguiam os pensamentos escolanovistas, como é possível observar no Manifesto dos Educadores Mais uma vez convocados: Manifesto ao povo e ao governo ${ }^{1}$ (1959):

Mas a educação pública por que nos batemos, ontem como hoje, é a educação fundada em princípios e sob a inspiração de ideais democráticos. A idéia da educação pública, - conquista irreversível das sociedades modernas; a de uma educação liberal e democrática, e a de educação para o trabalho e o desenvolvimento econômico e, portanto, para o progresso das ciências e da técnica que residem à base da civilização industrial, são três teses fundamentais defendidas por educadores progressistas do mundo inteiro. A educação tornou-se uma função ou caiu "sob a ingerência e direção do público", pela extensão, gravidade de suas consequências e sua qualidade de irreparáveis; e ao Estado que tem um papel social de assimilação, que estabelece "a solidariedade entre as diversas partes da comunidade nacional, as associa a uma vida comum, solda a dependência entre as gerações", nas palavras ele Félix Pécaut, compete, promovendo a educação pública, promover a convergência e a harmonia dos esforços humanos lá onde aqueles que olham de baixo não vêm senão luta $\mathrm{e}$ competição de grupos.

Com a promulgação da LDB de 1971, Lei n. 5.692/1971, à qual Demerval Saviani sujeita duras críticas e leva em consideração também a promulgação da Lei n. 5.540/1968, que, de acordo com Demerval Saviani, a respeito da situação política e social da época, também surge pós-Revolução de 1964, face à consolidação do processo de industrialização por meio da abertura ao capital estrangeiro em que para a burguesia e para a classe média haveria um ápice com sua finalidade nela mesma, como também para o operariado e para as forças da esquerda tratava-se apenas de uma etapa; até o momento em que a ideologia do nacionalismo desenvolvimentista deixou o cenário político do país, isto em decorrência da Lei n. 5.540/68 e do Ato Institucional n. 477/69, depois da crise de 1968 que culminou em uma reforma do ensino superior pelo governo.

Demerval Saviani (2013[1980], p. 188) pontua que a LDB n. 4.024/61 "embora pretendesse, como registra em sua ementa, tratar da 'Educação Nacional', limitou-se à organização escolar", além disso tendia a "regular o funcionamento e controle do que já estava implantado" e, em consequência disso, "os verdadeiros problemas educacionais permanecem intocados e a educação popular brasileira nem sequer foi considerada”, essa organização escolar "manteve, assim, sua característica de aparelho reprodutor

\footnotetext{
${ }^{1}$ Documento redigido por Fernando de Azevedo, a quem se atribui autoria, assinado por mais 160 educadores.
} 
das relações sociais vigentes”. O autor também pondera sobre as disparidades das Leis n. 4.024/61 e n. 5.540/68, além da n. 5.692/71, em que

\begin{abstract}
A inspiração liberalista que caracterizava a Lei n. 4.024 cede lugar a uma tendência tecnicista nas Leis n. 5.540 e n. 5.692. Enquanto o liberalismo põe a ênfase na qualidade em vez da quantidade; nos fins (ideais) em detrimento dos métodos (técnicas); na autonomia versus adaptação; nas aspirações individuais em vez das necessidades sociais; e na cultura geral em detrimento da formação profissional, com o tecnicismo ocorre o inverso. (p. 193)
\end{abstract}

A LDB n. 5.692/71, citada acima, reforça a nuança tecnicista em contraposição à LDB n. 4.024/61, "determinando preocupação com o aprimoramento técnico, com a eficiência e produtividade" (p. 193). Ademais, esta não dispõe de um capítulo destinado ao financiamento, dada a não obrigatoriedade legal da gratuidade no ensino superior, o contrário do que acontece com o ensino de $1^{\circ}$ e $2^{\circ}$ graus, gratuito e obrigatório, sendo dever do Estado, enquanto aquela não contém um capítulo destinado ao corpo discente porque regulamenta o ensino destinado a crianças e adolescentes e, além disso, tem dedicado ao financiamento o mais extenso de seus capítulos, o que indica uma tendência dominante.

A gratuidade do ensino em instituições oficiais é mencionada na LDB n. 9.394/96, em vigor atualmente com alterações ao longo dos anos, cuja obrigatoriedade passa a ser dos quatro anos de idade aos 17 , incluindo pré-escola, ensino fundamental e ensino médio, bem como estabelece acesso público e gratuito aos que não concluíram essas etapas em idade própria - idealização da EJA, por exemplo.

\title{
4 A educação para além da legislação
}

É importante compreender e elucidar que as legislações que regimentam o país, como no caso da educação, cativam um pensamento de igualdade e equivalência na atribuição dos direitos comuns à sociedade - todos têm os mesmo direitos - sem que, no entanto, se leve em consideração diversas condições de desigualdade e de injustiça. É por meio do discurso de igualdade, permeado pelos direitos iguais de acesso à educação, por exemplo, que se naturalizam situações de pobreza, de falta de acesso atribuídos ao não merecimento, principalmente quando as circunstâncias deflagram calamidade social partindo da lógica capitalista. Nesse sentido, como afirmam Lessa e Tonet,

O Estado capitalista, cuja expressão política mais acabada é a democracia burguesa, nada mais é, para Marx, do que o que todo Estado sempre foi: 
um instrumento especial de repressão a serviço das classes dominantes . O que torna o Estado burguês diferente do Estado escravista, ou mesmo do feudal, é que ele mantém e reproduz a desigualdade social afirmando a igualdade política e jurídica entre os indivíduos. Ele reproduz a desigualdade entre o burguês e o operário também pela ilusão de que, ao votar e eleger os políticos, a maioria da população estaria dirigindo o país. (2011 [2008], p. 85).

O Estado capitalista se ampara na ilusão de igualdade formal, política e jurídica a fim da manutenção da dominação burguesa sobre os trabalhadores. Nessa mesma perspectiva, compreendendo a educação como reflexo e incidências de ordem social, viver em uma sociedade capitalista torna suscetível a necessidade de uma "pedagogia revolucionária”, como aponta Demerval Saviani, a fim de que os interesses da classe não dominante se sobrepujem aos da burguesia, uma "pedagogia empenhada decididamente em colocar a educação a serviço da referida transformação das relações de produção” (2018 [1983], p. 61). Além disso, é necessário compreender que "a escola é determinada socialmente; a sociedade em que vivemos, fundada no modo de produção capitalista, é dividida em classes com interesses opostos; portanto a escola sofre a determinação do conflito de interesses que caracteriza a sociedade" (idem, p. 25) e, ainda que os professores não tenham consciência ou rejeitem essa ideia, a escola participa da luta de classes (DUARTE, 2016, p. 21).

A escolarização da classe trabalhadora, justamente o público-alvo da educação pública, é o que preocupa e ocupa a burguesia para a não efetivação da transmissão dos conteúdos clássicos por meio de recursos materiais e ideológicos.

No que diz respeito à escolarização da classe trabalhadora, a burguesia e os intelectuais a seu serviço há muito tempo vêm lançando mão de duas estratégias, a da seletividade e a da precariedade (...). Quando a seletividade precisa ser atenuada por alguma razão, acionam-se os mecanismos de precarização. Veja-se, por exemplo, na atualidade, a expansão da certificação em nível superior que, entretanto, se caracteriza cada vez mais por uma situação na qual as pessoas passam pelos cursos, obtêm seus diplomas, mas em termos de domínio de conhecimento pouco ou nada se modifica em comparação com o que a pessoa já sabia antes de fazer o curso. Asseverase no entanto, que essas pessoas adquiriram competências, aprenderam a aprender e desenvolveram seu potencial criativo. Assim como o que se valoriza hoje não é o emprego, mas a empregabilidade, também no campo escolar o que se valoriza não é o conhecimento que tenha sido adquirido, mas a formação da educabilidade, isto é, da disponibilidade para aprender de acordo com as exigências do momento, sejam elas determinadas pelo mercado de trabalho ou pelas mudanças na cotidianidade. (DUARTE, 2016, p. 26) 
A precarização da educação, pelo viés capitalista, gera consequências que, na atuação docente em qualquer perspectiva, tanto nas aulas, com relação aos métodos de ensino e abordagens conteudistas, quanto na escolha de material a ser utilizado em sala de aula - o livro didático é um recurso -; e a escolha desse material tem importância devido à sua incidência em sala de aula, cabe mencionar que o governo federal é um dos maiores consumidores desse material. A garantia de formação docente adequada garantiria subterfúgios para, além de uma atuação docente de qualidade, a escolha de material didático que atenda às necessidades da educação para a formação de outros indivíduos para a transformação humana por meio da educação, para a promoção do homem, como objetivo fundamental da educação.

\title{
50 livro didático
}

Em se tratando de legislação, é apenas na LDB n. 9.394/96 que há a garantia de material didático suplementar, ainda que, no entanto, o livro didático já fizesse parte do cotidiano escolar, uma vez que:

\begin{abstract}
O período compreendido entre as décadas de 1930 e 1960 caracterizouse, no que diz respeito aos manuais escolares, da seguinte forma: foram livros que permaneceram por longo período no mercado sem sofrerem grandes alterações; livros que possuíam autores provenientes de lugares tidos, naquela época, como de alta cultura, como o Colégio D. Pedro II; livros publicados por poucas editoras que, muitas vezes, não os tinham como mercadoria principal e, por fim, livros que não apresentavam um processo de didatização e adaptação de linguagem consoante às faixas etárias às quais se destinavam. (GATTIJR., 2004, p. 37)
\end{abstract}

É possível constatar, portanto, a existência do livro didático quando da promulgação da Lei n. 5.692/71. Demerval Saviani já discutia sobre a forma como a didatização ocorria, no entendimento de que o livro didático traz consigo conteúdo científico adaptado por meio de "mensagem educativa [...] convenientemente arranjada de modo que seja adequadamente captada pelo receptor (educando)" (2013 [1980], p. 132). Ainda sobre a diferença do discurso científico e do discurso didático, ainda que a transmissão do saber esteja condicionada à elaboração do saber, competência que não deve deixar de ser de interesse ao educador, por este estar na relação tríade como transmissor de uma mensagem - independente do meio pelo qual o faz - ao receptor, estabelece-se o seguinte:

o enunciado científico não procura, como o enunciado didático, que o interlocutor se identifique à matéria que enuncia e da qual está assim 
destruída a originalidade. Ao contrário, o discurso científico assegura a personalidade do pesquisador, pois que se situa no ponto em que se opõe a outras análises, ou que se confirma uma análise anterior, o que dá no mesmo, visto que é um corpo de propostas definidas por uma contestação (SAVIANI, 2013[1980], p. 132, apud DUBOIS; SUMPF, p. 156)

Caberia uma discussão curricular, sobre o modo como os currículos escolares funcionam desde sua inserção enquanto modo de organização curricular acadêmica que chega tão tardiamente ao ensino secundário, evidenciando um movimento que se designava a organizar as disciplinas nas universidades para, então, passar a organizar da mesma forma as séries antecedentes, pela designação "disciplina”. Sendo assim, os conteúdos passam a ser "concebidos como entidade sui generis, próprios da classe escolar, independentes numa certa medida, de toda realidade cultural exterior à escola", ou seja, denotam "os métodos e as regras para abordar os diferentes domínios do pensamento, do conhecimento e da arte" (CHERVEL, 1990, p. 180). Demerval Saviani, em entrevista concedida à Revista Escola, na edição de dezembro de 1972, em que estipula que "o fundamento da atividade sistematizadora é a consciência refletida que se apresenta como um dado estrutural da realidade humana" e, ainda, que "se educar é promover o homem, se promover o homem é ampliar a sua esfera de liberdade e de consciência, então quanto mais consciente for o homem, tanto mais humano ele será” (2011, p. 2). Além disso, o autor propõe condições para a promoção do homem por meio de um sistema educacional: a necessidade de consciência dos problemas nacionais e o conhecimento da realidade do país, e uma teoria educacional que parta dos pressupostos anteriormente mencionados.

Saviani propõe, ainda, que a educação se destina à promoção do homem de modo que a intenção de organização e sistematização do processo de ensino e aprendizagem atinja de forma adequada, eficaz e eficientemente esse objetivo fundamental. Reconhecendo também que o meio não tem sentido se não estiver impregnado de mensagem, bem como não tem sentido se a mensagem não se corporificar ao meio.

Os meios, o nome o diz, são aquilo que medeia, que se interpõe entre os polos da comunicação: o transmissor e o receptor; são, pois, os instrumentos que tornam possível a relação comunicativa. Esses três elementos (transmissor - meio - receptor) não são, porém, suficientes. Para que uma comunicação se realize, é necessário que haja algo a ser comunicado; é preciso, em suma, que haja uma mensagem. São quatro, portanto, os elementos fundamentais do processo comunicativo: alguém (transmissor) que tenha algo (mensagem) a transmitir a alguém (receptor) que capta a mensagem através de um veículo (meio). (SAVIANI, 2013 [1980], p. 130). 
Em se tratando de um país como o Brasil, com proporções continentais, entendendo que "a mensagem se liga imediatamente ao transmissor e mediante ao receptor, ao passo que o meio se liga imediatamente ao receptor e mediatamente ao transmissor", por isto, "a mensagem é determinada primordialmente pelas condições do transmissor, o meio o é pelas condições do receptor” (SAVIANI, 2013 [1980], p. 131), não é possível compreender que todas as condições do receptor sejam equivalentes, da mesma forma não são as condições do transmissor.

Uma das exigências da Lei n. 5.692/71 determinava o ensino, nas primeiras séries do primeiro grau, sendo ministrado predominantemente na forma de atividades, consequência do entendimento de que a mensagem é determinada pelas condições do transmissor e que o meio o é pelas condições do receptor.

Pode-se ainda inferir daí que, quanto mais concretos os instrumentos de comunicação, tanto maior o predomínio do meio sobre a mensagem (portanto, maior simplificação e particularização da mensagem). Tais conhecimentos são necessários ao educador, pois este terá que descobrir os instrumentos capazes de tornar a mensagem educativa assimilável pelo educando. Uma vez que o meio é determinado basicamente pelas condições do receptor, conclui-se que a escolha dos veículos da mensagem será determinada pelo conhecimento que o educador tem sobre o educando. (2013 [1980], p. 131).

Diante do exposto, é possível entender que o livro didático abrange parte do conjunto de recursos para o desenvolvimento desse processo e que, do ponto de vista do desenvolvimento cognitivo, o ser humano evolui das operações mais concretas para as mais abstratas. Sendo assim,

Isso significaria que o livro didático, enquanto recurso educativo (...) que sua faixa de referência se amplia (já que como instrumento mais abstrato ele propicia maior campo de abrangência) para se articular e, em certos casos, abarcar outros recursos pedagógicos. Em outros termos, caberá ao livro didático servir como elemento estimulador a professores e alunos no sentido de aguçar-lhes a capacidade criadora levando-os à descoberta e uso de novos recursos, por meio de sugestões múltiplas e ricas. (SAVIANI, 2013 [1980], p. 131-132).

Face à incidência do livro didático nas aulas, cabe discutir sobre a função delegada a esse material em vistas do processo de formação do educador e a sistematização do saber científico transmitido do educador para o educando. É possível depreender o livro didáti- 
co como instrumento adequado para a transformação da mensagem científica em mensagem educativa, tornando-se insubstituível porque os demais recursos não se prestam, da mesma forma como o livro didático (devido à sua abrangência), para a transmissão de conhecimentos sistematizados como o é aquele que constitui a ciência-produto (SAVIANI, 2013 [1980], p. 134). Nessa perspectiva, dado esse caráter de insubstutividade, o livro didático pode perder o caráter didático preenchendo o caráter educativo antes atribuído ao professor, como sujeito social possuidor de saber, sujeito que sabe o saber produzido pelos outros, e que o transmite.

De tal forma, João Wanderley Geraldi (2010, p. 85-86) aponta para uma distinção entre o professor - produtor e transmissor de conhecimento - que, até a segunda revolução industrial (séc. XVII até inícios do séc. XX), era definido como "aquele que sabe um saber produzido por outros e que o transmite a alunos", porque "como o professor não está produzindo o saber que ensina, ele está sempre atrás destes saberes que estão sendo produzidos por outros", sendo necessária atualização regular. E o professor que, com o desenvolvimento tecnológico, a partir da segunda revolução industrial (início do séc. $\mathrm{XX}$ ), passa a ser definido por "aquele que aplica um conjunto de técnicas de controle de sala de aula”.

\footnotetext{
Se há um deslocamento, digamos assim, na relação triádica professor, aluno e conhecimento, este deslocamento se dá no tipo de atuação do professor, pois a relação do aluno com o conhecimento não é mais mediada pela transmissão do professor, mas sim pelo material didático posto na mão do aprendiz, cabendo ao professor o controle do tempo, da postura e dos comportamentos dos alunos durante esta relação com o conhecimento através do material didático. Ao professor compete distribuir o tempo, distribuir as pessoas, e verificar se houve "fixação" do conteúdo, comparando respostas dos aprendizes com o "livro do professor", onde exercícios e tarefas são resolvidos e oferecem a chave de correção de qualquer desvio. (GERALDI, 2010, p. 86-87).
}

Sendo assim, o que antes era de responsabilidade da escola e do professor, passa a ser responsabilidade dos autores do material didático (ver Britto, 2003; Geraldi, 2010). Sendo assim, não haveria a necessidade de pensar o conhecimento ou reelaborá-lo atribuição de outras instâncias sociais: produção de conhecimento pelas universidades e centros de pesquisa e a seleção, a adaptação e a organização do conhecimento pelos autores do livro didático (BRITTO, 2003, p. 156). Alguns autores criticaram esse posicionamento na docência. De acordo com Britto (2003), 
[...] mais do que simplesmente estabelecer o conteúdo e o grau de detalhamento necessário em cada nível de ensino, o livro didático, ao pautar as falas e os comportamentos possíveis, instituindo uma voz fixa e norteadora de todas as ações. Ao trazer o programa, os modelos de avaliação, as perguntas e as respostas aos textos selecionados, faz do professor um gerente de aula, com a função de garantir a normalidade do processo.

Assim como Geraldi (2003 [1991]) que, ao tratar das aulas de professores que as gerenciam de acordo com conteúdos postulados previamente pelos LPDs, atribuindo a eles apenas o controle do tempo das atividades e a verificação se um conteúdo foi fixado ou não pelo aluno.

Em face do desenvolvimento tecnologizado, parece caber ao professor a escolha do material didático que usará na sala de aula. Mas qual a sua função depois disso? Uma boa metáfora é compará-lo a um capataz de fábrica: sua função é controlar o tempo de contato do aprendiz com o material previamente selecionado; definir o tempo de exercício e sua quantidade; comparar as respostas do aluno com as respostas do "manual do professor", marcar o dia da "verificação da aprendizagem" [...]. (GERALDI, 2003 [1991], p. 94).

Cabe assim, ao professor, de acordo com Geraldi (2010), apenas administrar a aula porque "abre-se todo o espaço para um tecnicismo da transmissão dos conhecimentos feitos conteúdos de ensino" (GERALDI, 2010, p. 88). O autor já apontava para um justificativa a esse retorno do tecnicismo porque compreendia que a incidência do material didático promove facilidade na/no tarefa/trabalho e diminui a responsabilidade, "o que permitiu elevar o número de horas-aula [...]; diminuir a remuneração [...]; contratar professores independentemente de sua formação ou capacidade, etc. Some-se tudo e temos ao menos uma pista para compreender o 'desprestígio' social da profissão.' (GERALDI, 2003 [1991], p. 94-95). Tal contexto não pode deixar de ser tomado como atual por conta da situação em que se encontram os professores, a escola e os alunos, bem como pela vigência neoliberal do governo atual que precariza as atribuições do Estado com o intuito de mostrá-las como deficitárias, o que preconiza intervenção pelo capital, privatização, ou contra o que os governantes chamam de ideologia em sala de aula. Retomo Geraldi, nas palavras do autor,

A relação direta entre aprendiz e o conhecimento através dos livros didáticos, do material didático, só teve o sucesso que teve entre nós, seguramente porque também se alteraram os próprios mecanismos de 
subjectivação dos sujeitos. $\mathrm{O}$ cuidado de si torna-se uma responsabilidade do próprio aprendiz. Quer dizer, ele tem que aprender a trabalhar com o material que o professor lhe entrega, que a escola lhe entrega. E ele tem de cuidar de si próprio. $\mathrm{E}$ isto implicará inúmeras mazelas que têm sido denunciadas pelo discurso crítico: realidades sociais, desvalorização das culturas escolarmente não rentáveis, etc. (GERALDI, 2010, p. 87-88).

Com a instrumentalização do livro didático, mesmo na pós-modernidade, tem-se uma didática fadada ao tecnicismo, tanto criticado na forma a que ficou condicionada a LDB n. 5.692/71 em contraposição ao liberalismo da LDB n. 4.024/61. A LDB n. 9.394/96 herda esse viés tecnicista vinculadas a um sistema de ensino que ainda propõe ao professor atender a demandas estritamente relacionadas às rotinas da escola, rotinas burocráticas de elaboração de proposta pedagógica, elaboração e cumprimento de plano de trabalho, zelo pela aprendizagem dos alunos, recuperação para alunos de menor rendimento, ministrar dias letivos e horas-aula estabelecidos e colaboração com a articulação entre escola, família e comunidade - atribuições reducionistas vinculadas ao papel do professor. E, como consequência disso, a culpabilização do aluno pela responsabilidade de ter de cuidar de si, ainda que haja sucesso escolar por determinados sujeitos subjacentes ao processo escolar.

Britto (2003), ao propor a análise de uma coleção de LDP não incluída no Guia do Livro Didático do MEC por não ser considerado de 'português', aponta para uma postura política por seguir uma lógica imediata do mercado apoiada no discurso de senso-comum escolar principalmente na adoção de metodologia para a escolha desse material que subjaz uma postura agentiva docente. $\mathrm{O}$ autor propõe o pensamento de num processo de retroalimentação contínua, que leva em consideração as condições de trabalho, a dificuldade de formação ou da imersão na cultura escolar, em que a leitura que os professores dispunham encontrava-se circunscrita aos materiais didáticos que atuariam na sua formação, ainda que destinados aos alunos (BRITTO, 2003, p. 160).

Por fim, Geraldi (2010) caracteriza a instituição escola, na contemporaneidade, desconectada dos propósitos de promoção do ser humano, que é o que defende Saviani (2013 [1980]), por uma educação que deixa de servir a um objetivo elementar da educação para servir ao capital.

a escola se faz, discursivamente, uma instituição 'tábua de salvação'. E como 'salvação' não sobrevive enquanto conceito sem associar-se à 'culpabilização', a escola tem sido culpada pelo insucesso de sua formação face às exigências do mercado. E as políticas neoliberais, para além de suas 
reformas curriculares que se constituíram essencialmente pela definição de parâmetros de conteúdos a serem ensinados e depois 'cobrados' nas avaliações nacionais e internacionais, não souberam fazer mais do que propor sistemas de avaliação e avaliação de sistemas/redes de ensino, sinalizando para o 'mercado consumidor' quais as escolas de nível A, quais as redes mais preparadas, quais as escolas aquinhoadas. (GERALDI, 2010, p. 91-92).

\section{Considerações finais}

Pautando os acontecimentos históricos à evolução do ser humano na sociedade pela forma como ela foi, ao longo dos anos, e é regimentada para sua organização, contata-se mudanças na forma como o ser humano configura o instrumento lei às suas necessidades. Ainda que politica e juridicamente se estabeleça certa noção de igualdade, as realidades em um país com proporção continental como o Brasil denotam e demonstram as mazelas de uma sociedade ainda injusta e inacessível no que diz respeito à educação. São essas leis que estabelecem critérios primordiais para que se alcance a inclusão e o direito a uma educação pública, gratuita e de qualidade, fadada ao sucesso que, para a educação, nada mais é - ou deveria ser - do que garantir a promoção do homem também por meio de um sistema educacional adequado, eficaz e eficiente. Essa promoção do homem, a ser 'garantida' pela educação, só é possível pela compreensão da importância do professor na tríade professor, aluno e conhecimento.

\section{REFERÊNCIAS}

AZEVEDO, Fernando de. Mais uma vez convocados: Manifesto ao povo e ao governo. Rev. HISTEDBR, Campinas. ago. 2006. p. 205-220. Disponível em: http:/ / www.histedbr. fe.unicamp.br/revista/edicoes/22e/doc2_22e.pdf. Acesso em: 20 de set. de 2019.

BARROS, Rubem. A história da LDB. Revista Educação. n. 235, dez. 2016. Disponível em: https://www.revistaeducacao.com.br/historia-da-ldb/. Acesso em: 22 de set. de 2019.

BRASIL. [Constituição (1988)]. Constituição da República Federativa do Brasil de 1988. Brasília, DF: Presidência da República, [2016]. Disponível em: http://www.planalto. gov.br/ccivil_03/constituicao/constituicao.htm. Acesso em: 1 de jul. de 2019.

BRASIL. [LDB (1996)]. Lei de Diretrizes e Bases da Educação Nacional de 1996. Brasília, DF: Presidência da República, [2016]. Disponível em: http://www.planalto. gov.br/ccivil_03/leis/19394.htm. Acesso em: 31 de jan. de 2020.

BRITTO, Luiz Percival Leme. O Leitor Interditado. In: BRITTO, Luiz Percival Leme. Contra o consenso. Cultura escrita, educação e participação. Campinas, SP: Mercado de Letras, 2003.

CHERVEL, André. História das disciplinas escolares: reflexões sobre um campo de pesquisa. Teoria \& Educação, n. 2, p. 177-229, 1990. 
DUARTE, Newton. Os conteúdos escolares e a ressurreição dos mortos. Campinas: Autores Associados, 2016.

GATTI JR., Décio. A escrita escolar da História: livro didático e ensino no Brasil (1970 1990). Bauru: Edusc, 2004.

GERALDI, João Wanderley. A aula como acontecimento. São Carlos, SP: Pedro \& João Editores, 2010.

LEONTIEV, A. A apropriação pelo homem da experiência sócio-histórica. In: LEONTIEV, A. O desenvolvimento do psiquismo. Lisboa: Livros Horizontes, 1959. p. 176186.

LESSA, Sérgio; TONET, Ivo. Introdução à filosofia de Marx. 2. ed. São Paulo: Expressão Popular, 2011 [2008].

SAVIANI, Demerval. Educação: do senso comum à consciência filosófica. 19. ed. Campinas: Autores Associados, 2013.

SAVIANI, Demerval. Educação em diálogo. Campinas: Autores Associados, 2011.

SAVIANI, Demerval. História das ideias pedagógicas no Brasil. 2. ed. Campinas: Autores Associados, 2007.

SAVIANI, Demerval. Pedagogia histórico-crítica: primeiras aproximações. 11. ed. rev. Campinas: Autores Associados, 2013.

SAVIANI, Demerval. Escola e democracia. 43. ed. rev. Campinas: Autores Associados, 2018.

VOLOCHÍNOV, V. N. As mais recentes tendências do pensamento linguístico ocidental. In: VOLOCHÍNOV, N. V. A construção da enunciação e Outros ensaios. São Carlos: Pedro \& João Editores, 2013 [1928], p. 101-130.

VOLOCHÍNOV, V. N. Marxismo e filosofia da linguagem: problemas fundamentais do método sociológico na ciência da linguagem. Tradução, notas e glossário de Sheila Grillo e Ekaterina Vólkova Américo. 1 ed. São Paulo: Editora 34, 2017 [1929].

VOLOCHÍNOV, V. N. Que é linguagem. In: VOLOCHÍNOV, N. V. A construção da enunciação e Outros ensaios. São Carlos: Pedro \& João Editores, 2013 [1930], p. 131-156.

Data de submissão: 05/02/2020

Data de aceite: $20 / 04 / 2020$ 